\title{
PENGEMBANGAN MODUL PENYELESAIAN GARIS LEHER PADA MATA KULIAH TEKNOLOGI BUSANA JURUSAN IKK FPP UNP
}

\author{
Vina Mayangsari ${ }^{1 *}$, Adriani ${ }^{2 *}$ \\ Program Studi Pendidikan Kesejahteraan Keluarga Jurusan Ilmu Kesejahteraan Keluarga \\ Fakultas Pariwisata dan Perhotelan \\ Universitas Negeri Padang \\ Jl. Prof. Dr. Hamta, Air Tawar Padang, Kel. Air Tawar Barat, Kec. Padang Utara, Kota Padang, Kode Pos 25171 \\ Sumatera Barat. Indonesia \\ Email:vina.mayangsari48@gmail.com
}

\begin{abstract}
Abstrak
Penelitian ini bertujuan untuk membuat media pembelajaran berupa Modul Penyelesaian Garis Leher pada jurusan IKK FPP UNP. Penelitian ini juga bertujuan untuk melihat kelayakan dari validitas dan praktikalitas modul tersebut. Penelitian ini menggunakan metode Research and Development (R\&D). Proses dalam penelitian ini meliputi define, design dan develop. Teknik pengumpulan data yang dipakai pada penelitian ini adalah observasi dan angket, yang dimana data didapatkan dari uji validitas, dan uji praktikalitas dari dosen Pembina mata kuliah dan mahasiswa. Hasil dari penelitian ini yaitu hasil uji validitas didapatkan skor $87.1 \%$ dengan kategori sangat valid. Uji praktikalitas didapatkan skor $85.6 \%$ dengan kategori sangat praktis. Dapat disimpulkan bahwa Modul Penyelesaian Garis Leher ini dapat dikategorikan layak untuk digunakan sebagai media pembelajaran pada Mata Kuliah Teknologi Busana.
\end{abstract}

Kata Kunci: media pembelajaran, busana, garis leher.

\begin{abstract}
This research aims to produce an instructional media Neckline Finishing Module at IKK FPP UNP. This research also aims to know about advisability of validity and practicality of the module. This research was conducted using Research and Development $(R \& D)$. The method of this research include define, design and develop. The technique of accumulation data were observation and questionnaire, which the data was from validity test, practicality test of both small and large group of college student and also practicality test of advisor of Fashion Technology course subject. The result of this research show that from the validity of module score $87.1 \%$ which categorized as very advisability. Practicality test of module score $85.6 \%$ which categorized as very practical. So we can conclude that Neckline Finishing Module can be categorized as very advisable to use as instructional media at Fashion Technology subject.
\end{abstract}

Keywords: instructional media, fashion, neckline.

\section{PENDAHULUAN}

Mata kuliah Teknologi Busana merupakan Mata Kuliah wajib Keilmuan dan Keterampilan (MKK) konsentrasi Pendidikan Tata Busana pada Jurusan PKK konsentrasi Tata Busana yang berbobot 3 SKS (1 Teori, 2 Praktek). Mata Kuliah wajib ini dapat diikuti mahasiswa pada semester 1 (satu) masa perkuliahan. Mata Kuliah ini wajib diambil oleh mahasiswa konsentrasi Pendidikan Tata Busana.

Berdasarkan hasil observasi dan wawancara, peneliti menemukan temuan bahwa mahasiswa kesulitan dalam mempraktekkan penyelesaian garis leher yang terletak pada pemahaman teknik menjahit, dikarenakan mata pelejaran teknologi busana mereka pelajari pada semester pertama perkuliahan mereka dan tidak sedikit dari mereka yang merupakan pemula dalam bidang tata busana, sehingga mereka membutuhkan suatu media yang dapat membantu mereka dalam memahami teknik-teknik penyelesaian garis leher.

Selain itu mahasiswa tersebut juga kesulitan untuk menyelesaikan tugas penyelesaian garis leher tepat waktu pada saat pembelajaran tatap muka dikampus sehingga mereka harus menyelesaikan tugas-tugas 
tersebut diluar jam pelajaran secara mandiri dirumah masing-masing, namun saat menyelesaikan tugas secara mandiri, mereka kesulitan untuk mendapatkan pedoman atau petunjuk dari teknik penyelesaian garis leher dikarenakan masih kurangnya sumber/literature tentang teknik penyelesaian garis leher, sehingga mereka membutuhkan media yang dapat membantu mereka bekerja secara mandiri.

Untuk mengatasi permasalahan tersebut, maka perlu adanya usaha yang dilakukan oleh mahasiswa dan dibantu oleh dosen sebagai pembimbing dalam pembelajaran dan saling mendukung tugas dan tanggung jawab masing-masing agar terlaksana dengan baik. Dikarenakan hal tersebut, penulis memilih untuk melakukan pengembangan modul karena karakteristik modul sesuai dengan apa yang dibutuhkan untuk menyelesaikan permasalahan yang dialami oleh mahasiswa pada mata kuliah teknologi busana.

Menurut Santyasa (2009:9) Sistem pembelajaran dengan menggunakan modul adalah suatu sistem pembelajaran yang efektif, efesien dan relevan dalam pendidikan yang disusun untuk dipelajari secara mandiri dalam mencapai tujuan pendidikan yang telah dirumuskan.

Sistem pembelajaran modul akan menjadikan pembelajaran yang lebih baik. Pembelajaran dengan modul juga memberikan kesempatan bagi mahasiswa untuk belajar menurut cara masing-masing, karena menggunakan teknik yang berbeda-beda untuk memecahkan masalah tertentu berdasarkan latar belakang pengetahuan dan kebiasaan belajar masingmasing.

\section{KAJIAN TEORI}

Garis Leher ialah salah satu bagian dari pakaian. Karningsih (2013:35) mengemukakan bahwa "Garis leher adalah bagian ujung atas pakaian yang terletak di sekitar leher. Garis leher memiliki beberapa bentuk, seperti bulat, persegi, segitiga dan yang lainnya. Dalam penyelesaiannya garis leher tersebut diselesaikan dengan penyelesaian garis leher".

Sejalan dengan pendapat sebelumnya, Lilik (2013:106) juga mengemukakan bahwa "Garis leher merupakan bagian pakaian yang terletak paling atas. Bentuk garis leher banyak variasinya, yangumum dipakai yaitu leher bulat". Dari beberapa pendapat tersebut dapat kita simpulkan bahwa yang dimaksud dengan garis leher merupakan salah satu bagian dari
Gorga Jurnal Seni Rupa

Volume 08 Nomor 01 Januari-Juni 2019

p-ISSN: 2301-5942 | e-ISSN: 2580-2380

busana yang terletak pada bagian atas busana, tepatnya pada bagian leher.

Penyelesaian garis leher dengan lapisan atau juga dapat disebut dengan facing merupakan penyelesaian garis leher yang dimana jika model atau desain garis leher tidak dipasangkan kerah. Menurut Julie (2009:315) "penyelesaian garis leher dengan lapisan merupakan penyelesaian dengan menyambukangkan sehelai kain ke garis leher untuk menyelesaikan garis leher tersebut". Sejalan dengan pendapat sebelumnya, Alison (2009:143) juga mengemukakan bahwa "penyelesaian garis leher dengan lapisan adalah menyelesaikan garis leher dengan bahan yang ditempeli dengan pelapis/interfacing dengan menyambungkannya ke garis leher yang akan diselesaikan".

Claire (1994:72) mengemukakan bahwa penyelesaian garis leher dengan lapisan memiliki 3 cara yaitu :

1. Lapisan menurut bentuk (Shaped facing)

2. Lapisan Extended Facing

3. Lapisan Dengan Ban (Bias Facing).

Kerah merupakan salah satu bagian-bagian busana yang terletakpada bagian leher. Menurut Uswatun (2011:27) bahwa :

"Kerah adalah bagian dari busana yang dijahitkan/dipasangkan pada garis leher, kerah memiliki konstruksi dan bentuk yang bervariasi. Kerah dapat berfungsi sebagai center of interest (pusat perhatian) untuk menambah keindahan busana serta dapat menutupi dan menonjolkan bentuk wajah."

Dari pendapat diatas dapat kita ulas bahwa kerah merupakan salah satu bagian dari busana yang kita jahitkan pada bagian leher dan memiliki bentuk dan kontruksi yang bervariasi dan juga dapat menjadi salah satu titik pusat perhatian dari pakaian.

Selain pendapat tersebut, Simon dalam Wildati (2007:145) juga mengemukakan bahwa "kerah adalah bagian utama dan merupakan penyelesaian dari suatu pakaian sebagai penghias, pelengkap atau penekanan pada garis leher." Sedangkan menurut Charlotte dan Phyllis dalam Wildati (2007:146) "kerah adalah bagian terpisah yang melekat pada item pakaian di leher untuk menyelesaikan tepi leher."

Kerah dibagi menjadi beberapa jenis kerah. Uswatun (2011:27) mengelompokkan kerah menjadi 3 (tiga) jenis, yaitu : 1) Kerah Berdiri, 2) Kerah Setengah Berdiri, dan 3) Kerah Rebah. 


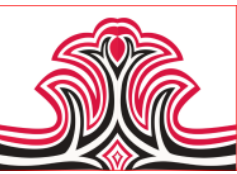

\section{METODE PENELITIAN}

Penelitian ini merupakan penelitian pengembangan (Research and Development). Menurut Sujadi (2003:164) "Metode penelitian dan pengembangan (Research and Development) adalah suatu proses atau langkah-langkah untuk mengembangkan suatu produk baru, atau menyempurnakan produk yang ada, yang dapat dipertanggung jawabkan".

Penelitian pengembangan modul ini dikembangkan dengan dilakukan uji coba pada mahasiswa PKK Konsentrasi Pendidikan Tata Busana semester JuliDesember 2018.

Dalam prosedur penelitian pengembangan ini menggunakan model pengembangan 4-D (Four D). Menurut Thiagarajan, dkk dalam Zainal (2012:128) Model ini terdiri dari 4 tahap pengembangan yaitu : Define (Pendefinisiaan) , Design (Perancangan), Develop (Pengembangan), dan Disseminate (Penyebaran). Namun pada penelitian ini tahap Disseminate (penyebaran) belum dapat dilakukan karena memerlukan waktu yang panjang, jumlah sampel yang banyak serta memerlukan dana yang lebih besar. Maka dari itu peneliti akan melaksanakan 3 tahap, yaitu Define, Design dan Develop.

\section{HASIL DAN PEMBAHASAN}

\section{Hasil}

\section{1). Tahap Pendefenisian (Define)}

Pada tahap pendefinisian, penulis melakukan analisisanalisis yang yang nantinya akan menjadi pedoman untuk proses pembuatan modul penyelesaian garis leher. Dalam tahap ini peneliti menemukan masalah yang menjadi latar belakang pembuatan modul, yaitu 1) Masih terbatasnya literatur/sumber bacaan mahasiswa tentang teknik Penyelesaian Garis Leher pada Mata Kuliah Teknologi Busana yang dapat menuntun mahasiswa untuk belajar secara mandiri. 2) Belum tersedianya modul untuk materi Penyelesaian Garis Leher pada Mata Kuliah Teknologi Busana yang telah valid dan praktis. 3) Kurangnya pengetahuan mahasiswa tentang teknik Penyelesaian Garis Leher. 4) Mahasiswa kesulitan dalam menyelesaikan tugas Penyelesaian Garis Leher sehingga harus menyelesaikan tugas-tugas diluar jam pelajaran secara mandiri.

\section{2).Tahap Perencanaan (Design)}

Dalam tahap perancangan peneliti menganalisis kebutuhan dari modul penyelesaian garis leher, lalu menetapkan kerangka garis-garis besar modul pembelajaran dan menyusun kerangka modul
Gorga Jurnal Seni Rupa

Volume 08 Nomor 01 Januari-Juni 2019 p-ISSN: 2301-5942 | e-ISSN: 2580-2380

pembelajaran. Modul yang dirancang terdiri dari 3 kegiatan pembelajaran yang memiliki judul sebagai berikut : 1) Penyelesaian Garis Leher, 2) Penyelesaian Garis Leher dengan Lapisan, 3) Penyelesaian Garis Leher dengan Kerah.

Komponen-komponen Modul Penyelesaian Garis Leher pada Mata Kuliah Teknologi Busana yang telah dirancang terdiri dari cover luar, cover dalam, kata pengantar, daftar isi, daftar gambar, peta kedudukan modul, deskripsi umum, petunjuk kegunaan modul, bab I Pendahuluan, bab II Pembelajaran, evaluasi akhir, kunci jawaban, bab III penutup, glosarium dan daftar pustaka.

\section{3). Tahap Pengembangan (Develop) \\ (1).Validasi Modul Pembelajaran}

Validasi modul pembelajaran pada penelitian ini dilakukan oleh 2 orang ahli media dan 2 orang ahli materi. Tahap validasi ini dilakukan untuk menghasilkan modul pembelajaran yang valid dan sesuai dengan yang dibutuhkan oleh mahasiswa. Setelah melalui proses validasi maka modul yang dikembangkan akan menjadi valid dan layak untuk digunakan sebagai modul pembelajaran.

Hasil validasi media terhadap Modul Penyelesaian Garis Leher dirangkum berdasarkan kategori validasi yang dinilai sebagaimana terlihat pada table berikut

Tabel 1. Hasil Validasi Media Modul Pembelajaran

\begin{tabular}{|l|l|l|l|}
\hline No & $\begin{array}{l}\text { Indikator } \\
\text { Penilaian }\end{array}$ & $\begin{array}{l}\text { Hasil } \\
\text { Validasi } \\
(\boldsymbol{\%})\end{array}$ & Kategori \\
\hline 1 & Desain Sampul & $79 \%$ & Valid \\
\hline 2 & $\begin{array}{l}\text { Desain Isi } \\
\text { Modul }\end{array}$ & $89 \%$ & $\begin{array}{l}\text { Sangat } \\
\text { Valid }\end{array}$ \\
\hline 3 & Isi Modul & $84 \%$ & $\begin{array}{l}\text { Sangat } \\
\text { Valid }\end{array}$ \\
\cline { 1 - 3 } 4 & Bahasa Modul & $80 \%$ & Valid \\
\hline Jumlah & 332 & $\begin{array}{l}\text { Sangat } \\
\text { Valid }\end{array}$ \\
\hline \multicolumn{2}{|l|}{ Rata-rata } & $\mathbf{8 3}$ &
\end{tabular}

Berdasarkan tabel diatas dapat dilihat bahwa terdapat empat aspek yang dinilai, yaitu desain sampul, desain isi modul, isi modul dan Bahasa modul. Berdasarkan tabel diatas dapat disimpulkan bahwa pada uji validasi diperoleh skor $83 \%$ dengan kategori sangat valid.

Hasil validasi materi terhadap Modul Penyelesaian Garis Leher dirangkum berdasarkan kategori validasi yang dinilai sebagaimana terlihat pada tabel berikut. 
Tabel 2. Hasil Validasi Materi Modul Pembelajaran

\begin{tabular}{|c|c|c|c|}
\hline No & $\begin{array}{l}\text { Indikator } \\
\text { Penilaian }\end{array}$ & $\begin{array}{l}\text { Hasil } \\
\text { Validasi } \\
(\%)\end{array}$ & Kategori \\
\hline 1 & Kelayakan Isi & $95 \%$ & $\begin{array}{l}\text { Sangat } \\
\text { Valid }\end{array}$ \\
\hline 2 & $\begin{array}{l}\text { Keakuratan } \\
\text { Materi }\end{array}$ & $88 \%$ & $\begin{array}{l}\text { Sangat } \\
\text { Valid }\end{array}$ \\
\hline 3 & $\begin{array}{l}\text { Pendukung } \\
\text { Materi } \\
\text { Pembelajaran }\end{array}$ & $93 \%$ & $\begin{array}{l}\text { Sangat } \\
\text { Valid }\end{array}$ \\
\hline 4 & $\begin{array}{l}\text { Kemutakhiran } \\
\text { Materi }\end{array}$ & $95 \%$ & $\begin{array}{l}\text { Sangat } \\
\text { Valid }\end{array}$ \\
\hline 5 & $\begin{array}{l}\text { Teknik } \\
\text { Penyajian }\end{array}$ & $90 \%$ & $\begin{array}{l}\text { Sangat } \\
\text { Valid }\end{array}$ \\
\hline 6 & $\begin{array}{l}\text { Pendukung } \\
\text { Penyajian }\end{array}$ & $83 \%$ & $\begin{array}{l}\text { Sangat } \\
\text { Valid }\end{array}$ \\
\hline 7 & $\begin{array}{l}\text { Penyajian } \\
\text { Pembelajaran }\end{array}$ & $100 \%$ & $\begin{array}{l}\text { Sangat } \\
\text { Valid }\end{array}$ \\
\hline 8 & $\begin{array}{l}\text { Kelengkapan } \\
\text { Penyajian }\end{array}$ & $87 \%$ & $\begin{array}{l}\text { Sangat } \\
\text { Valid }\end{array}$ \\
\hline 9 & Tugas & $93 \%$ & $\begin{array}{l}\text { Sangat } \\
\text { Valid }\end{array}$ \\
\hline 10 & Komunikatif & $90 \%$ & $\begin{array}{l}\text { Sangat } \\
\text { Valid }\end{array}$ \\
\hline 11 & $\begin{array}{l}\text { Kesesuaian } \\
\text { dengan } \\
\text { Perkembangan } \\
\text { Mahasiswa }\end{array}$ & $90 \%$ & $\begin{array}{l}\text { Sangat } \\
\text { Valid }\end{array}$ \\
\hline \multicolumn{2}{|c|}{ Jumlah } & 1004 & \multirow{2}{*}{$\begin{array}{l}\text { Sangat } \\
\text { Valid }\end{array}$} \\
\hline Rat & rata & 91,2 & \\
\hline
\end{tabular}

Berdasarkan tabel diatas dapat dilihat bahwa validasi materi dilihat dari sebelas aspek yang akan dinilai. Berdasarkan tabel diatas didapatkan rata-rata skor 91,2\% dengan kategori sangat valid.

\section{(2).Praktikalitas Modul Pembelajaran}

Data uji praktikalitas Modul Penyelesaian Garis Leher sebagai media pembelajaran diambil dari angket yang telah dibagikan pada dosen dan mahasiswa.

\section{a.Uji Praktikalitas Berdasarkan Respon Dosen Mata Kuliah}

Data praktikalitas berdasarkan respon dosen diperoleh melalui angket yang diisi oleh dosen Pembina mata kuliah Teknologi Busana yaitu Ibu Reni Fitria, M.Pd. Hasil penilaiannya penulis rangkum pada tabel berikut:

Tabel 3. Uji Praktikalitas Dosen Pembina Mata Kuliah
\begin{tabular}{|c|l|l|l|}
\hline No & $\begin{array}{l}\text { Indikator } \\
\text { Penilaian }\end{array}$ & $\begin{array}{l}\text { Hasil } \\
\text { Praktikalitas } \\
(\%)\end{array}$ & Kategori \\
\hline 1 & $\begin{array}{l}\text { Kelayakan } \\
\text { Tampilan }\end{array}$ & $88 \%$ & $\begin{array}{l}\text { Sangat } \\
\text { Praktis }\end{array}$ \\
\hline 2 & $\begin{array}{l}\text { Penyajian } \\
\text { Materi }\end{array}$ & $85 \%$ & $\begin{array}{l}\text { Sangat } \\
\text { Praktis }\end{array}$ \\
\hline 3 & Manfaat & $94 \%$ & $\begin{array}{l}\text { Sangat } \\
\text { Praktis }\end{array}$ \\
\hline Jumlah & 267 & $\begin{array}{l}\text { Sangat } \\
\text { Praktis }\end{array}$ \\
\hline Rata-rata & $\mathbf{8 9}$ & 29
\end{tabular}

Gorga Jurnal Seni Rupa

Volume 08 Nomor 01 Januari-Juni 2019

p-ISSN: 2301-5942 | e-ISSN: 2580-2380

Berdasarkan tabel diatas dapat dilihat pada uji praktikalitas dosen Pembina terdapat tiga aspek, yaitu kelayakan tampilan, penyajian materi dan manfaat. Berdasarkan tabel tersebut dapat disimpulkan bahwa uji praktikalitas dosen Pembina mata kuliah didapatkan rata-rata skor $89 \%$ dengan kategori sangat praktis.

\section{b.Uji Praktikalitas Berdasarkan Respon Mahasiswa Kelompok Kecil}

Uji praktikalitas kelompok kecil dipilih 5 orang diambil dari 30 orang mahasiswa prodi pendidikan kesejahteraan keluarga konsentrasi tata busana angkatan 2018 yang mengambil mata kuliah teknologi busana. Hasilnya dapat dilihat pada tabel sebagai berikut.

Tabel 4. Uji Praktikalitas Mahasiswa Kelompok Kecil

\begin{tabular}{|l|l|l|l|}
\hline No & $\begin{array}{l}\text { Indikator } \\
\text { Penilaian }\end{array}$ & $\begin{array}{l}\text { Hasil } \\
\text { Praktikalitas } \\
(\%)\end{array}$ & Kategori \\
\hline 1 & $\begin{array}{l}\text { Kelayakan } \\
\text { Tampilan }\end{array}$ & $83 \%$ & $\begin{array}{l}\text { Sangat } \\
\text { Praktis }\end{array}$ \\
\hline 2 & $\begin{array}{l}\text { Penyajian } \\
\text { Materi }\end{array}$ & $79 \%$ & Praktis \\
\hline 3 & Manfaat & $83 \%$ & $\begin{array}{l}\text { Sangat } \\
\text { Praktis }\end{array}$ \\
\hline Jumlah & 245 & $\begin{array}{l}\text { Sangat } \\
\text { Praktis }\end{array}$ \\
\hline \multicolumn{2}{|l|}{ Rata-rata } & $\mathbf{8 2}$ & \multicolumn{2}{|l}{}
\end{tabular}

Berdasarkan tabel diatas dapat dilihat bahwa terdapat tiga aspek, yaitu kelayakan tampilan, penyajian materi dan manfaat. Berdasarkan tabel tersebut dapat disimpulkan bahwa uji praktikalitas mahasiswa kelompok kecil mendapatkan rata-rata skor $82 \%$ dengan kategori sangat praktis.

\section{c.Uji Praktikalitas Berdasarkan Respon Mahasiswa Kelompok Besar}

Uji praktikalitas kelompok besar dilakukan setelah melalui uji praktikalitas kelompok kecil. Setelah mahasiswa memahami modul pembelajaran yang diberikan kepada mahasiswa yang mengambil mata kuliah teknologi busana uji praktikalitas kelompok besar ini dilakukan oleh 30 orang mahasiswa dengan hasil seperti pada tabel di bawah ini.

\section{Pembahasan}

Sebagaimana pendapat Direktorat Tenga Kependidikan (2008) Tujuan pembuatan modul salah satunya adalah untuk dapat mengatasi keterbatasan waktu, ruang dan daya indera baik peserta belajar maupun dosen/instruktur. Keterbatasan waktu yang dimaksud ini adalah waktu dalam pembelajaran penyelesaian garis leher pada mata kuliah teknologi busana dimana keterampilan yang harus dimiliki oleh 
setiap mahasiswa dapat tersalurkan secara utuh dalam waktu relatif singkat. Modul yang dihasilkan juga telah memenuhi kriteria sebuah media yang praktis dan dapat membantu fungsi dosen sebagai fasilitator dalam pembelajaran dengan aspek penilaian kelayakan tampilan, penyajian materi dan manfaat sebuah media pembelajaran (modul) yang mewakili pencapaian nilai kepraktisan suatu bahan ajar.

Maka dapat disimpulkan bahwa modul Penyelesaian Garis Leher yang dikembangkan adalah 'sangat praktis' dan layak digunakan pada pembelajaran teknologi busana pada materi penyelesaian garis leher.

\section{KESIMPULA DAN SARAN}

\section{Kesimpulan}

Berdasarkan hasil penelitian yang telah dilakukan, adapun kesimpulan dalam penelitian ini adalah :

Modul penyelesaian garis leher ini dikembangkan sebagai media pembelajaran yang berbentuk hardcopy yang tersusun sesuai RPS mata kuliah teknologi busana yang disajikan dalam bentuk teks dan gambar yang menarik dan full colour yang dapat digunakan oleh mahasiswa secara mandiri. modul ini terdiri dari 206 halaman dan 3 kegiatan pembelajaran, dalam kegiatan pembelajaran terdapat materi penyelesaian garis leher, penyelesaian garis leher dengan lapisan dan penyelesaian garis leher dengan kerah. Setiap langkah dilengkapi dengan gambar dan keterangan sehingga mempermudah mahasiswa dalam belajar secara praktek, setiap kegiatan pembelajaran dilengkapi dengan rangkuman dan tes formatif dan taka motivasi untuk membangkitkan semangat belajar mahasiswa. Pada bagian akhir terdapat evaluasi yang dilengkapi dengan kunci jawaban, glosarium dan daftar pustaka.

Uji validitas Modul Penyelesaian Garis Leher pada Mata Kuliah Teknologi Busana berdasarkan rekapitulasi hasil penilaian ahli media dan ahli materi diperoleh rata-rata nilai $87,2 \%$ dengan kategori sangat valid, artinya modul tersebut sudah layak diuji cobakan kepada mahasiswa.

Uji praktikalitas Modul Penyelesaian Garis Leher pada Mata Kuliah Teknologi Busana berdasarkan respon dosen Pembina mata kuliah teknologi busana dan mahasiswa dalam uji coba kelompok kecil dan kelompok besar diperoleh rata-rata nilai $86 \%$ dengan kategori sangat praktis, artinya modul tersebut sudah dapat digunakan oleh mahasiswa sebagai sumber belajar dalam perkuliahan teknologi busana.
Gorga Jurnal Seni Rupa

Volume 08 Nomor 01 Januari-Juni 2019 p-ISSN: 2301-5942 | e-ISSN: 2580-2380

\section{Saran}

Bagi mahasiswa diharapkan dapat memanfaatkan modul pembelajaran penyelesaian garis leher untuk menunjang proses belajar yang lebih baik lagi sehingga menghasilkan generasi yang memiliki kecakapan ilmu pengetahuan dan praktik khususnya dalam teknik penyelesaian garis leher.

Bagi pengajar dan dosen yang mengajar mata kuliah teknologi busana diharapkan agar dapat memanfaatkan modul pembelajaran penyelesaian garis leher ini dan mengimplementasikannya dalam perkuliahan.

Bagi peneliti sendiri semoga dapat menambah wawasan pengetahuan dan pemahaman materi tentang penyelesaian garis leher dan menjadi pengalaman berharga untuk kesempatan pengembangan media lainnya dikemudian hari.

Bagi peneliti selanjutnya semoga dapat menyempurnakan segala kekurangan pada media pembelajaran modul penyelesaian garis leher ini, dapat melanjutkan penelitian ketahap efektifitas dan tahap penyebaran (disseminate)

\section{DAFTAR RUJUKAN}

Alison, Smith. (2009). The Sewing Book. United States: DK Publishing.

Claire, Shaeffer. (1994). Couture Sewing Technique. United States: The Taunton Press.

Direktorat Tenaga Kependidikan. (2008). Penulisan Modul. Jakarta: Direktorat Jendral Peningkatan Mutu Pendidikan dan Tenaga Kependidikan Departemen Pendidikan Nasional.

Julie, Cole. (2009). Professional Sewing Technique for Designers. United States : Fairchild Books, Inc.

Lilik, Trajuningtyas. (2013). Teknik Menggambar Busana. Jakarta : Kementerian Pendidikan dan Kebudayaan.

Santyasa. (2009). MetodePenelitian Pengembangan dan Teori Pengembangan Modul. Bandung: Universitas Pendidikan Ganesa.

Sujadi. (2003). Metodologi Penelitian Pendidikan. Jakarta: Rineka Cipta.

Uswatun, Hasanah. (2011). Menggambar Busana. Jakarta: Rosda.

Wildati, Zahri. (2007). Teknologi Menjahit Pakaian. Padang: UNP Press.

Zainal, Arifin. (2012). Penelitian Pendidikan : Metode dan Paradigma Baru. Bandung: PT Remaja Rosdakarya. 